\title{
X. Remarks on the present state of botanical classification
}

\author{
Sir Edw.Ff. Bromhead Bart. M.A. F.R.S.L. E.
}

To cite this article: Sir Edw.Ff. Bromhead Bart. M.A. F.R.S.L. E. (1837) X. Remarks on the present state of botanical classification, Philosophical Magazine Series 3, 11:64-65, 48-54, DOI: $10.1080 / 14786443708649228$

To link to this article: http://dx.doi.org/10.1080/14786443708649228

曲 Published online: 17 Jun 2009.

Submit your article to this journal $₫$

Џlll Article views: 3

Q View related articles $₫$ 
Doubtless the true composition is

4. atoms carbonate of barytes,

4 atoms carbonate of lime,

1 atom carbonate of manganese and iron.

Thus it appears that neither Mr. Johnston nor myself had given a correct analysis of the mineral. It is a triple instead of a double salt. I failed in discovering the manganese, in consequence of having neglected to examine the calcareous residue: Mr. Johnston failed in consequence of dissolving the mineral in muriatic instead of nitric acid. This last acid should always be used in examining the earthy carbonates, because it enables us to see by the colour when any iron or manganese is present.

A name derived from the constituents of so complicated a mineral would be unwieldy. Perhaps the term bromlite, derived from its best known locality, would be as unexceptionable as any.

$$
\text { I am, \&c., }
$$

Thomas Thomson.

Glasgow, June 3, 1837.

X. Remarks on the present State of Botanical Classification. By Sir Edw. Fr. Bromiead, Bart., M.A., F.R.S.L.S.E.*

T $\mathrm{T}$ seems to be agreed among botanists that the natural families must be arranged upon some new system; and it is also understood that the first attempt must consist in forming natural alliances or assemblages of such as are in immediate undisputed affinity with each other. Each family must be related to every other family within the alliance, and I have elsewhere explained the artifice by which a first approximation may be made.

The question of linear arrangement is not necessarily connected with this stage of the inquiry; if such be the order of nature, the primary alliances will throw themselves into sequence almost spontaneously; if not, some other principle will shortly show itself. In the mean time, to give the future result fair play, we should endeavour to place the families within our alliances in their natural order of transition, as we endeavour to arrange genera within families and species within genera. The tendency to circulation will no doubt always offer difficulties; it would almost seem as if the progress of development were represented by a thread wound spirally round a rod, on which the point immediately above another appears

* Communicated by the Author 
to be the nearest, though distant by a whole round of the spiral.

The extent of these alliances does not yet rest upon any fixed principle. Linnæens and Adanson throw plants into fifty-eight assemblages, and we must consider a botanical family of that day as representing the alliance of our own time. Bartling makes sixty clasmes or alliances. The annexed table makes sixty alliances also, averaging each about five fanilies. Those of Dr. Lindley are more nunerous, areraging rather less than three families; he seems to have looked for consolidation in I s groups, and precision in the alliances. The alliances of the table sometimes correspond with Dr. Lindley's groups, as in Curvembryose, Aggregose, Glumosa, Spadicosa, but they more generally correspond with his alliances; the smaller alliances of Dr. Lindley must however continue under any scientific classification as suballiances.

In the revised table, the improved nomenclature of $\mathrm{Dr}$. Lindley is of course usually adopted; his work on the Natural System must henceforth be a standard of reference everywhere; and there is much convenience in the definite manner by which such reference points out the tribes and genera intencled to be included. His happy manner of designating the alinances by a termination in ales is also adopted. In amending the nomenclature, it were to be further wished that botanists would regularly designate all the families from generic names, throwing aside names from species or obsolete genera, and all characteristic or arbitrary or mutilated names. Such a regular system might, by a slight modification of the termination, lead hereafter to a convenient mode of indicating the position of ench family in the general system.

The limits of families are often at present more a matter of taste than of defunite distinction: Arnott has in doubtful cases made good use of suborders as superior to tribes and sections. The average points to five families for each alliance, and it may be as well to lean towards that number; nothing would be more easy than to reduce the whole to that standard; we sometimes have the choice of more than one combination, or sometimes a more easy adaptation to a ternary or senary division. Numerical symmetry is, however, a suspicious circumstance in natural history, though it is possible that an antecedent, normal, and succeeding state may occasionally be distinctly marked.

In the first approximations for forming the table, the character's were studiously kept out of sight. Every one nuust feel, on trial, the bias against evidence, where it is required to modify a scheme for the admission of something additional, Third Series. Vol.11. No.64. July 1837. 
and also the tendency to cut off families at the limits of an alliance for the sake of rounding the character. After the first grouping the investigation of characters will, of course, be found useful; it will settle the limits of an alliance, where a family has stood ambiguously between (wo; it will negatively settle the place of many doubtful tamilies; it will shake heterogeneous alliances, and confirm such as are sound.

The characters must be formed on the rohole structure; it may in a few instances be possible to point out an assemblage of families by some happy peculiarity, but such is not the plan of nature, in which even species require an enumeration of many parts. The utmost extent of simplification will be a statement of the Normal structure (the Nixus of Dr. Lindley), followed by remarks on the limits of deviation and equivalent changes. The error in this case has arisen from the received notion, that every species passes imperceptibly into some other; such, however, may not be the case, - a change of one particular part generally inplies, in natural history, some corresponding change of every other part, so that families may differ more abruptly than genera, and alliances more abruptly than families. In some families the differences of adjoining species are much greater than in others.

A collection of characters is necessary also for ascertaining the nuture of the properties which usually extend over a succession of families; the properties which most conveniently distinguish genera are often of little value to distinguish families, and those which separate adjoining families will probably have little further range. In this research it is mortifying to find a property rumning through the greater part of an alliance, and often passed by in the remainder as being unimportant within the usual limits of classification. The characters may too frequently amount to nothing, or indicate merely that there is not a deviation from general normal structure; but such were some of the characters of Jussien. They may often be negative, but such are more definite than any other, and may hereafter be pushed to any extent, so as to form differential characters between any two alliances whatsoever.

Results apparently trivial should be admitted, where they offer themselves, as it is impossible to foresee what may serve to illustrate the general progress of structure. Where a property occurs through an alliance, with comparatively trifling exception, it should be given, and the exception stated; the place of the excepted family may be shaken, or some remarkable equivalence of structure may be discovered.

Bartling very properly gives the lead to the structure of the stem, foliation, and inflorescence, as Linnæus does in the 
elegant sketches of his Botanical Philosophy. Those properties are not often used in distinguishing genera, and are comparatively neglected by many late writers; they will probably hereafter rise to importance, and it may be found useful to refer to the older writers, who laid so much stress on foliation.

In giving the characters it is necessary to use a modified language of a greater breadth of expression than usual.

I have collected some materials for ascertaining the founders of the different allinces in the table; and the first publisher must be so considered, even were it thought to be the result of an indistinct happy accident. liew writers can take the range of a whole science and instinctively select from the mass whatever is well founded. Writers min see the truth placed before them, but seeing it mixed up with objectionable matter, they may throw it aside, and afier long incpuiry and many qualifications, may find on reference the final result of their labours to be the same. Science herein differs from literature, that the truth must bring two writers to the same point; but it is also true that we may let the result of our reading digest with the mass of our ideas, until we mistake for the produce of our own minds what we met with elsewhere. Frequently, by a kind of compulsion, after long research the views of others are adopted. The annexed table has thus been most materially improved, and was in some parts new cast, from the many new affinities and assemblages discovered by the acuteness of Bartling and Lindley.

Of the 60 alliances in the table, (in the next page) it is highly satisfactory to find that nearly 50 have been substantially indicated by the first names which botany can produce:Agardh, Bartling, Brown, Casalpinus, Decandolle, Hedwig, A. L. de Jussien, Ad. de Jussieu, Lindley, Linnaus, Morison, Ray, Reichenbach, Richard, Riudolphi, Schultes, St. Hilaire, Wallenbergh. The particulars of their discoveries, and the characters of the botanical formations and alliances which I have prepared, would extend these remarks much too far.

[See the "Intellizence and Miscellaneons Articles" of the present number for some remarks on the introductory passages of the foregoing paper, prepared for insertion as a note, but for which there is not room in this place. EDrT.] 


\title{
THE ULVACEOUS RACE*.
}

\author{
[Fucaceac,' chondraccac,' ULVACE.IL,' nostocaceae,' diatomacete, ]
}

(†) Confervaceae, ${ }^{1}$ снаклесау, equisetaceae, (si illariaceae, )

Ophioglossaceae, danæaceae-OSMUND A CE A E-gleicheniaceae, poly podiaceae, Cycadaccae, mphedraces, casuarinaceae,

† Myricace 2 , platanaceae-(moracex: $:^{2}$ ) itraces-(fothergilleae,) (empetraceae, stilaginaceae, scepaceæ,

Trewiace $x$, hensloviacese batider, $(\uparrow)$ U RTICACEA E, cannabinea, datiscaceae,

Iacistemaceae, chloranthaceae, garryactac, nargeiace ${ }^{2}$ - PI'ERACEA E-Saururaceae, podostemaceae,

Ceratophylleae, hippurideae, ${ }^{3}$ callitri haceae, nalonaGeae, trapacea,

Circaeae-fENOTHERACFAE-montiniea, [ tlythracese, (†)rbizophoraceat, vochyaceae, tcombretaceae,

Memecylaceae, melastomaceae, alangiaceae, lecythidaceac-barringtoniea, ] †и uTACEA-puniceae,

Pyraceae, amygdaleae, tchrysobalanaccae-tsanguisorbeae, (neillieact)-quillaiaespiraae, (†) ROSACE $A$ - - potentillea,

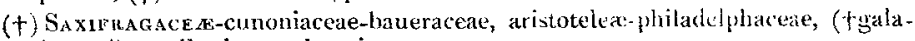
cincae, ${ }^{4}$ ) escalloniaceae, bruniacene,

Ribesiaceae, [tmelocactaceae, CUCUR I I T CEA E, hegoriceae, loasaceae,]

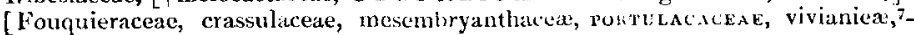
tsilenaceæ-falsinaceae, ]

(†) Illecebraces, +CHENOPODI A CE A E, ${ }^{9}$ tphytolaccaceae, ${ }^{9}$ tpolygonaceac, mirabiliaceae-salvadoracea,

Staticeae-plumbaginaceac, polmosiactar, cobracede, diapensiacca, hydroleacere, Hydrophyllaceat, BOR A GINACLAE, heliotropiceae, ehretiaceae, cordiaceae,

Nolanaceae, $\left[(\dagger)\right.$ verbasceae- $(\dagger) \mathrm{di}_{0}$ italea-salpiglossideac, soLAAACEAL-(cestracer, $\left.)\right]$ convolvulaceat, cuscutaceae,

Ieiphaimea, 2 [(retziacex, ) menyantheae, fortianacese, spigeliaceae,

(†) A POCYN ACE $\mathbb{E}$, asclepiadaceae, carissex-rauwolfiex, ] potaliaceae-loganiaceae, lygodysodeaceae,

fCinchonaceae, opercularincae, GalaCbat, lonicereac-sambuceae, apiaced,

(†) A raliaccae, loranthaceae, ( $\dagger$ )hamamelaccae, convacsab-hederaceae, ${ }^{\text {i }}+$ vitaceae, GER ANIACEZE, surianacea, limnanthaceac, tropacoleae-balsaminaceae, foxalidaceae,

[Reaumuriaceae-(tamaricaceae,) datinaceae-linaceae, cIstaceaf,] resedaceæ, polygalace -krameriaceæ,

Tremandracea, cappareae-cleomeae, bRassicacen E, fumarieae, papaveraceae,

[NY MPH A ACEA E, nelumbiaceae, (†)cephalotaceae, hydropeltideae-podophylleae, preonieae, 7

Cimicifuge ${ }^{7}$-clematideae-tranunculaceae, SARRACKN1ACEAv,] aristolochiaceae, nepenthaceae, (fcytinaceae, ${ }^{9}$ )

(†) Pistiaceae, thydrocharaceae, ALISTACE a F, butomaceae, pontederaceae,

Commelinaceac-philydracese, xyridaceae-restiaceae-desvauxiaceae, cyperaceae, A VEN ACE $\mathrm{K}$, cocoaccae,

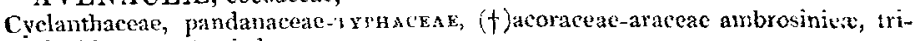
glochinaceae, t naiadaceat,

* The synbols and references are explained in $p .51$ 


\section{THE USNEACEOUS RACE.}

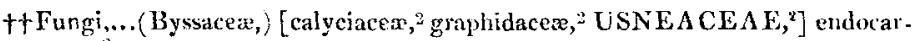
paceæ, ${ }^{2}$

Riccieae-marchantiex, JUNGEMMAN NIACRAv, andreaceae-bryacee,

Salviniaceae-marsileaceae, isoëteae $-\nmid L$ Y COPODI ACE AE, lepidodendrea, ${ }^{2}$

(Salisburiaceae)-†taxaceae, cupressinaE, tpinacea-araucariec,

Liquidambraceae, salicaceac, BETU LACEAr, carpineae-frorylaceae, jugiandaccac,

Anacardiaceae-spondiaceae, burseraceae, chailletiaceae, nitrariaceae-(neuradeac,) RHAMNACEAE,

Coriariaceae, (†)xuphorbiaceae, stackhousiaceae, celastraceae-staphyleaceaethippocrateae, erythroxylcae,

Nalpighiaceae, $(\dagger)$ aceraceae, Asculace.s, millingtoniex-sapindaceae, caryocaraceae,

†Clusiaceæ, marcgraaviaceae, HY PE R ICACFAE, (ochranthacex)-carpodonteae, tcamelliaceae,

Rhodolænaceae, humiriaceae, (hugoniacew)-(canellex,) meliaceae-cedrelaceae, LIMONLACEAE,

Amyridaceae, tconnaraceae, minoseae-detarieae, swaxtzicae-pFABACEAE, geoffroyeae-cæsalpinieae,

Moringaceae, [wormskioldia'- + frankeniaceae-sauvagesiae, $(\dagger)$ parnassieae, 7 droseraceae, WVIOLACFAE,

+PASSIFLOR A CE A E-natesherbiaceae, turneracene, caricaceae, belvisiaceae, patrisieae-flacourtiaces,

+ Bixaceae, pangiaceae, samydaceae, hom a LAcE $x_{\text {, ] }}$ aquilariaceie,

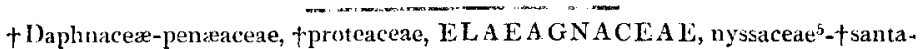
laceac-anthobolea, olacaceac,

Oleaceae jasminaceae, columelliaceae-gesneraceae, pinguiculacca, Acaxrmacka , cyrtandraceæ-bignoniaceae-pedaliaceae,

Stilbacex, selaginaceae, myoporacea, tverbenacea, I A M I A C E A E-ocimoideae, Buddleiex-buchnerex, tgratiolex, (tveronicea,) hemineridea, antirrhineaegerardieae-†rHinanghese, orobanchaceae,

Monotropaceae- $(\uparrow)$ pyrolaceæ, $\nmid \mathbf{E}$ RICACEA, epacridaceae, andromedex, vacciniaceae,

CA M A NULACEAE-lobeliaceae, stylidiaceae, pongatiacea, goodeniaceatscaevolacede brumoniaceat,

Asteracea-cichoracea-mutisiacet-cysaracke, valerianaceae, calyceraceat, dipsacacese-glooulariaceac, tplantaginaceac,

+Primulaceae-trynsinacean, achrabaceae, (t)styracea-diospyraceac, ilicaceabresiaceae, pittosperaceac,

t'Lygophyllaceae, $\uparrow$ RU'Y A CE $F$, txanthoxylaceae, simarubaceae, ochnaceae,

Dipterocarpaceae, elacocarpaceae. $(\dagger)$ tiliaceae, byttneriea-dombeyae-bombaceae, MaLvaCEA,$(†)$ sterculiaceae,

Myristicacee, hernandiaceae, illigeraceae, cassythaceae, LAUrackar,

Atherospermaceat, monimiaceae, calycanthacese, illicieae-MAGNOLIACE $\mathbb{E}$, tdilleniaccae,

Schizandreae, fanonaceae, $(\dagger$ ) berberaceae, lardizabalc $x$, Menisfremaceas, *

Smilaceae-dioscoreaceae- + roxburghiaceae, †ASPARAGACEA, ${ }^{9}(\dagger)$ juncaceae-gilliesiaceae, themerocallace ${ }^{9},(+)$ molunthincea,

Iridaceae, apostasiaceae, ORCHID ACE E-vanillaceae, zingiberacea-maranta ceae-musaceac, tamaryllidaceae,

Hypoxideae agavex, †romelackar, wachentorficae ${ }^{7}$-thanodoraceae, buman niaceae, taccaccae,... Balanophoraceae, ${ }^{3}$ 


\section{E M O R A N D A.}

A series of Fanilies in immediate and continuous affinity with each other, is called an AI.LANCE, and is indicated by a termination in ales:- Ex. Osmundales are the Ferns.

Parallel Alliances are called Formagrons*, and are indicated by a termination osc:-Ex. Iamiosa include Iamiales and Boraginales, the Nucamentosat of 1)r. Lindley.

Series of successive alliances are called unrons:-Ex. The Passifloral Union in. cludes Violales, Passiflorales, and Itomaliales, nearly the Parietosae of Dr. Lindley. [ Indicates that the order of succession among the families so included is not settled.

( ) Indicates that the evidence for the station is more conflicting than usual.

$f$ Indicates that the Fanily or Tribe may be compound. Tribes are occasionally inserted to show transitions.

The Nomenclature of Dr. Lindley's System is usually taken as the standard.

(1) Agardh's Fucoidex, floridea, ulvacex, nostochina, diatomex, confervoidem.

(2) Here separated.

(3) Link.

(4) D. Don.

(5) Jussieu.

(6) Bartling.

(7) Arnott.

(8)

(9) Chenopodiaceae here includes Sclcrantliaceae-amarantacea-fchenopodiace Phytolaccaceæ includes Tetragoniaceae-phytolaccaceæ-petiveriaceæ. Cytinaceae includes Rafflesiacea.

Cynaraceæ-followed by (Xeranthemeæ)-calendulacee-arctotidex.

Asparagaceae includes Convallarina-parideæ-asparageæ-aloine-antherices. Hemeracallaceae includes + Scillea-hemerocallidea-tulipea.

Balanophoraceae includes Cynomoriacex.

XI. Observations on the Deduction of the Dere-point from the Indications of the Wet-bulb Thermometer, and on the Detection of minute quantities of foreign Matters diffised in the Atmosphere; with Nolices of Apparatas. By JoHn PriDEAUX, member of the Plymouth Institution; in a letter to Mr. Brayley. Dear Sir,

THE wet-bulb thermometer, preferable to other hygrometers from the permanence, directness, and simplicity of its action, has the inconvenience of its indications being not only subject to necessary calculations, but also, hitherto, to considerable discrepancy in the principles on which these computations are made; and to corresponding differences in the resulting dew-points, even supported by irreconcileable experiments. The pages of the Philosophical Magazine have been so largely occupied in the discussion of these principles, that it is not my intention to go much into them on the present occasion ; on which I will offer little more than a compari-

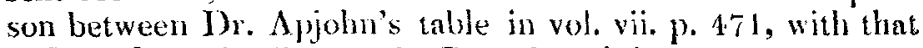
of Dr. Mason in Thomson's Records, vol. iv. p. 109.

\footnotetext{
* I term used by Reichoubach.
} 